\title{
CS-19 Bioactividad de extractos de especies vegetales nodrizas de bosques de pinabetes (Abies guatemalensis) de Ixchiguán, San Marcos, Guatemala
}

\author{
Bioactivity of extracts from nurse plants species from fir (Abies guatemalensis) forests from \\ Ixchiguan, San Marcos, Guatemala \\ Stella Cruz-Bolaños ${ }^{1}$, Deyling Maldonado-de León ${ }^{1}$, José V. Martínez-Arévalo², Armando Cáceres ${ }^{1 *}$ \\ ${ }^{1}$ Escuela de Química Biológica, Facultad de Ciencias Químicas y Farmacia y ${ }^{2}$ Subárea de Ciencias Biológicas, Facultad de \\ Agronomía, Universidad de San Carlos de Guatemala, Guatemala.
}

*Autor al que se dirige la correspondencia: acaceres46@gmial.com

\section{Resumen}

$\mathrm{P}$ lantas nodrizas son aquellas especies útiles para la sobrevivencia y convivencia de otras especies. Abies guatemalensis Rehder (pinabete) es una especie endémica en peligro de extinción y para asegurar su sobrevivencia es necesario estudiar sus plantas nodrizas. Se colectaron seis especies de plantas nodrizas de bosque Los Cuervos, Ixchiguán, San Marcos y se secaron a la sombra en un horno, hasta obtener un porcentaje de humedad $<10 \%$. Se obtuvieron extractos etanólicos usando un rotavapor; los aceites esenciales por hidrodestilación con Neoclevenger. Para los análisis de actividad se montaron ensayos biocidas contra bacterias, hongos, levaduras, larvas de insectos, nauplios de Artemia salina y actividad antioxidante. Los aceites esenciales presentaron un porcentaje de rendimiento menor del $0.3 \%$, siendo muy volátiles y difícil su análisis. Los extractos etanólicos demuestraron poca actividad antimicrobiana y larvicida (CIM: $1 \mathrm{mg} / \mathrm{mL}$ ). La actividad atrapadora de radicales libres evaluados por DPPH dio buenos resultados con Acaena elongata $\left(\mathrm{CI}_{50}\right.$ de $\left.0.22 \pm 0.01 \mathrm{mg} / \mathrm{mL}\right)$ y Rubus trilobus $\left(\mathrm{CI}_{50} 0.32 \pm 0.01\right.$ $\mathrm{mg} / \mathrm{mL})$ y actividad moderada con Buddleja megalocephala $\left(\mathrm{CI}_{50} 0.76 \pm 0.04 \mathrm{mg} / \mathrm{mL}\right)$. Estos hallazgos estimulan a continuar la investigación de plantas nodrizas para conocer las moléculas responsables de la actividad antioxidante y definir su posible aplicación como antioxidantes para la prevención o tratamiento de patologías humanas o para la preservación de alimentos o uso cosmético, permitiendo que las comunidades las cuiden y aprovechen.

Palabras claves: Amaranthus hybridus, Cnidoscolus aconitifolius, Lycianthes synanthera

\section{Abstract}

$\mathrm{N}$ urse plants are species useful for the survival and coexistence of other plants. Abies guatemalensis Rehder (fir) is an endemic species in danger of extinction and in order to ensure its survival, it is necessary to study their nurse plants. Six species of nurse plants were collected from Los Cuervos forest, Ixchiguán, San Marcos, they were dried in the shade and in an oven until a moisture content $<10 \%$ was obtained. Ethanol extracts were obtained by rotavapor; biocidal assays were established against bacteria, fungi, yeasts, insect larvae, nauplii of Artemia salina and antioxidant activity. Essential oils were obtained by hydrodistillation with Neoclevenger. The essential oils yields were $<0.3 \%$, being very volatile and dificult tu analyze. Extracts have little antimicrobial and larvicidal activity with a MIC: $1 \mathrm{mg} / \mathrm{mL}$ of the ethanol extracts. The free radical trapping activity assay evaluated by DPPH, yielded good results: Acaena elongata $\left(\mathrm{IC}_{50}\right.$ of $\left.0.22 \pm 0.01 \mathrm{mg} / \mathrm{mL}\right)$ and Rubus trilobus $\left(\mathrm{IC}_{50} 0.32 \pm 0.01\right.$ $\mathrm{mg} / \mathrm{mL}$ ) and a moderate activity in Buddleja megalocephala $\left(\mathrm{IC}_{50} 0.76 \pm 0.04 \mathrm{mg} / \mathrm{mL}\right)$. These findings stimulate research on nurse plants to know the molecules responsible for the antioxidant activity and to define its possible application for the prevention or treatment of human pathologies or for the preservation of food or cosmetic use, allowing the communities to take advantage and to take care of them. 